\title{
EFEKTIVITAS KUIS DALAM MENINGKATKAN HASIL BELAJAR IPS SISWA KELAS VI SDN 8 KERUAK KECAMATAN KERUAK KABUPATEN LOMBOK TIMUR.
}

\author{
JAMLUDDIN1 ${ }^{1}$ \\ STIT PALAPA NUSANTARA LOMBOK NTB \\ Jamilpacu@gmail.com
}

\begin{abstract}
This study aims to describe the effectiveness of quizzes in improving the learning outcomes of IPS students grade VI SDN 8 Keruak Keruak District East Lombok regency. This study was categorized into experimental research. The population of this study is all students of class VI SDN 8 Keruak amounted to 22 students. The sample of this study consists of two classes, namely the experiment as many as 11 people and control class as many as 11 people. Sample determination is done by using purposive sampling technique. The technique used to collect research data is a test technique. The collected data was analyzed using descriptive statistical technique of $\mathrm{t}$ tes ttype. The results showed that the effective quiz was applied in improving the learning outcomes of IPS students of grade VI SDN 8 Keruak. That is, the quiz is a strategy that can change the process (shaping student learning behavior) and student learning outcomes. This is evident in both research classes. For the control class, students' attitudes and attitudes toward IPS learning are lacking. Unlike experimental class students, students' attitudes and attitudes toward IPS learning are very high. The increase in results appears in the acquisition of the average grade of the experimental class better than the average value of the control class.
\end{abstract}

Kata Kunci: Efektivitas, Kuis, Hasil Belajar

\section{PENDAHULUAN}

Proses belajar mengajar adalah rangkaian kegiatan yang di dalamnya terjadi kontak komunikasi antara seorang guru sebagai pengajar dan siswa sebagai pelajar. Guru sebagai motivator dalam proses belajar mengajar hendaknya mampu memilih metode yang dapat menimbulkan rasa ingin tahu, memvariasikan cara mengajar dan pola interaksi dalam kelas agar pencapaian materi pelajaran tersebut lebih efektif dan efisien. Selain itu, guru harus memberi motivasi agar siswa senang dan tekun belajar.

Proses perkembangan ilmu pengetahuan dan teknologi serta pelaksanaan proses belajar mengajar sangat kompleks. Hal ini didukung oleh ketiga komponen pembelajaran dalam proses

\footnotetext{
${ }^{1}$ JAMILUDDIN STIT PALAPA NUSANTARA LOMBOK NTB
} 
belajar mengajar, yakni guru, siswa, dan sarana pendidikan yang mempunyai peranan penting sehingga harus mendapatkan perhatian yang lebih khusus. Guru dan siswa harus diperhatikan terutama kebutuhan dalam pembelajaran dan sarana harus selalu siap ketika dibutuhkan sehingga dapat menopang proses belajar mengajar yang maksimal. Namun, perlu dipahami bahwa keberhasilan proses belajar mengajar sangat ditentukan oleh guru. Guru yang kreatif dan inovatif merupakan kunci keberhasilan pembelajaran. Salah satu bentuk kreativitas guru adalah menerapkan kuis pada setiap proses belajar mengajar. Hal ini dinyatakan karena kuis merupakan salah satu bentuk penilaian dan strategi guru untuk memotivasi belajar siswa.

Siswa akan tekun belajar apabila mengetahui bahwa guru selalu memberikan kuis setiap awal atau akhir pembelajaran. Hal ini dilakukan sebagai pembuktian kepada guru bahwa siswa bisa dan merupakan salah satu wujud penilaian bagi guru. Dengan demikian, dapat dinyatakan bahwa dalam pembelajaran yang terjadi di sekolah atau khususnya di kelas, guru adalah pihak yang paling bertanggungjawab atas keberhasilan siswa. Dengan demikian, guru perlu membekali diri dengan teknik dan bentuk kuis sebagai ilmu yang mendukung tugasnya.

Sehubungan dengan diadakannya kuis, siswa dapat mengetahui tingkat keberhasilan mengikuti pelajaran yang diberikan oleh guru. Jika siswa memperoleh hasil yang memuaskan dan hal itu menyenangkan, tentu ia ingin mengulangnya. Dengan demikian, siswa mempunyai motivasi yang besar untuk belajar lebih giat agar mendapat hasil yang lebih memuaskan.

Berdasarkan uraian tersebut pelaksanaan kuis bermanfaat untuk mengetahui penguasaan materi yang telah diajarkan, menilai dan mengukur pengetahuan, dan kemampuan siswa. Namun, kenyataan di lapangan menunjukkan bahwa guru terkadang tidak memperhatikan pemberian kuis yang hanya disebabkan oleh kesempatan atau waktu yang terbatas. Berdasarkan latar belakang tersebut, rumusan masalah penelitian ini, yaitu: Apakah kuis efektif diterapkan dalam meningkatkan hasil belajar IPS pada siswa kelas VI SDN 8 Keruak Kecamatan Keruak Kabupaten Lombok Timur. Sehubungan dengan permasalahan tersebut di atas, tujuan penelitian ini, yaitu mendeskripsikan efektivitas kuis dalam meningkatkan hasil belajar IPS pada siswa kelas VI SDN 8 Keruak Kecamatan Keruak Kabupaten Lombok Timur.

\section{KAJIAN PUSTAKA}

\section{Kuis}

Kuis adalah sebuah pelatihan yang diberikan kepada siswa setiap akhir pembelajaran. Kuis ini berupa poin-poin pertanyaan tentang mateni yang baru saja diberikan kepada siswa. Setiap 
kali siswa diberikan kuis, maka pada pelajaran berikutnya hasil kuis tersebut dikembalikan disertai dengan tanggapan dan koreksi dari guru.

Anderson (dalam Nurgiyantoro) menyatakan bahwa dalam proses belajar-mengajar, kuis adalah serentetan pertanyaan, bentuk latihan lain yang digunakan un tuk mengukur keterampilan, pengetahuan, intelegensi, kemampuan atau bakat yang dinilai oleh individu atau kelompok. ${ }^{2}$

Kuis merupakan bentuk tes tanya jawab atau tes lisan yang jawabannya menggunakan bahasa lisan atau tes dalam bentuk pertanyaan dari guru harus dijawab oleh siswa secara lisan. Setiap pertanyaan yang diajukan oleh guru dimaksudkan untuk memotivasi siswa serta menemukan sendiri informasi pengetahuan baru untuk mengembangkan kemampuan berpikir kritis, logis, dan sistematis.

Adapun hal-hal yang perlu diperhatikan sebagai berikut:

a. Ciri-ciri pertanyaan yang baik, antara lain:

1) merangsang siswa untuk berpikir;

2) jelas dan tidak menimbulkan banyak tafsiran;

3) singkat dan mudah dipahami oleh siswa;

4) disesuaikan dengan tingkat kemampuan berpikir siswa

b. Teknik mengajukan pertanyaan kuis, antara lain:

1) pertanyaan diajukan kepada seluruh siswa;

2) berikan waktu yang cukup kepada siswa untuk berpikir;

3) diusahakan setiap siswa diberi giliran menjawab;

4) dilakukan dalam suasana rileks, tidak dalam keadaan tegang.

c. Sikap guru terhadap jawaban siswa, antara lain:

1) tafsiran jawaban siswa ke arah yang baik;

2) hargai secara wajar sekalipun jawaban siswa kurang tepat;

3) pada saat-saat tertentu, berikan kesempatan kepada siswa lain menilai jawaban yang diberikan temannya. ${ }^{3}$

Hasil pembelajaran dalam kegiatan belajar mengajar ditujukan oleh perubahan tingkah laku. Hal ini dapat diketahui dengan menggunakan alat ukur berupa tes atau kuis. Kuis merupakan satuan alat ukur dalam pembelajaran yang harus ada sejak pengajaran dimulai sampai

\footnotetext{
${ }^{2}$ Nurgiyantoro dan Burhan. Penilaian dan Pengajaran Bahasa dan Sastra. Yagyakarta: BPFE.1995.hlm 56

${ }^{3}$ Azwar dan Saifuddin. Tes Prestasi. Yogyakarta: Pustaka Pelajar. 1987.hlm 13
} 
selesai untuk mengetahui apakah siswa menge ${ }^{\mathrm{ii}}$ rti atau tidak dengan hal-hal yang sedang dipelajarinya.

\section{Hasil Belajar}

Pada hakikatnya, manusia belajar karena mempunyai bakat untuk belajar yang dipicu oleh hasrat ingin tahu dan didukung oleh kemampuan untuk mengetahui. Belajar merupakan suatu proses, suatu kegiatan, dan bukan suatu hasil atau tujuan. Belajar bukan hanya mengingat, melainkan meliputi kegiatan yang lebih luas, yakni mengalami. Hasil belajar bukan merupakan penguasaan terhadap hasil latihan, melainkan perubahan tingkah laku. ${ }^{4}$

Belajar itu terjadi bila seseorang menghadapi suatu situasi yang di dalamnya ia tidak dapat menyesuaikan diri dengan menggunakan bentuk-bentuk kebiasaan untuk menghadapi tantangan atau apabila ia harus mengatasi rintangan dalam aktivitasnya. Jika demikian, belajar dapat didefinisikan sebagai suatu proses kegiatan yang menimbulkan kelakuan baru untuk mengubah kelakuan lama sehingga seseorang lebih mampu memecahkan masalah dan menyesuaikan diri terhadap situasi-situasi yang dihadapi dalam hidupnya.

Pengertian di atas memberikan pemahaman bahwa belajar merupakan aktivitas yang dilaksanakan secara sadar untuk mendapatkan sejumlah kesan dan bahan yang telah dipelajari. Hasil aktivitas belajar adalah perubahan dalam diri individu. Jadi, belajar dapat dikatakan berhasil bila terjadi perubahan dalam diri individu. Sebaliknya, bila tidak terjadi perubahan dalam diri individu, belajar dikatakan tidak berhasil. Belajar merupakan proses perkembangan hidup manusia. Melalui proses belajar, manusia melakukan perubahan-perubahan kualitatif sehingga tingkah lakunya berkembang. Semua aktivitas dan prestasi hidup tidak lain adalah hasil belajar.

Hasil belajar ditandai oleh perubahan tingkah laku yang terjadi pada diri seseorang yang melakukannya. Abdurrahman menjelaskan bahwa belajar adalah interaksi individu dalam lingkungan yang membawa perubahan sifat, tindakan, perbuatan, dan tingkah laku. ${ }^{5}$

\section{METODE PENELITIAN}

Variabel penelitian ini, yaitu efektivitas kuis dalam meningkatkan hasil belajar IPS pada siswa kelas VI SDN 8 Keruak Kecamatan Keruak Kabupaten Lombok Timur. Desain penelitian

\footnotetext{
${ }^{4}$ Hamalik, Oemar, Proses Belajar Mengajar. Bandung: Bumi Aksara. 1994 hlm: 36

${ }^{5}$ Abdurrahman.Dasar-dasar Publik Relation. Bandung: Alumni. 1994: hlm 97
} 
yang digunakan adalah desain penelitian yang bersifat eksprimen, dengan rancangan sebagai berikut.

$\begin{array}{llcr}\text { Kelompok } & \text { Pretes } & \text { Tindakan } & \text { Postes } \\ \text { Kontrol } & \mathrm{X} & - & \mathrm{X} \\ \text { Eksperimen } & \mathrm{X} & \mathrm{X} & \mathrm{X}\end{array}$

Berdasarkan rancangan tersebut dapat dinyatakan bahwa kedua kelas diberikan tes awal untuk mengetahui perbandingan pengetahuannya. Selanjutnya, dilakukan perlakuan dengan memberikan kuis bagi kelas eksperimen sebelum evaluasi akhir dan tidak memberikan kuis bagi kelas kontrol sebelum evaluasi akhir. Jadi, penelitian ini merupakan penelitian eksperimen yang melibatkan dua kelompok, yaitu kelompok kontrol (kelompok yang tidak diberikan kuis sebelum evaluasi) dan kelompok eksperimen (kelompok yang diberi tindakan berupa pemberian kuis sebelum evaluasi).

Adapun Populasi penelitian ini adalah siswa kelas VI SDN 8 Keruak Kecamatan Keruak yang berjumlah 22 siswa. Untuk lebih jelasnya, tampak pada Tabel 1 berikut.

\section{Tabel 1}

Keadaan Populasi

\begin{tabular}{|c|c|c|}
\hline No. & Kelas & Jumlah \\
\hline 1. & VII & 22 orang \\
\hline & Jumlah & 22 orang \\
\hline
\end{tabular}

\section{Sumber: Tata Usaha SDN 8 Keruak Kecamatan Keruak}

Penarikan sampel dilakukan dengan cara sampel total (total sampling), yaitu melakukan penarikan sampel dengan mengambil keseluruhan sebagai sampel. Jadi, sampel penelitian sebanyak 22 orang yang dibagi ke dalam dua kelompok, yaitu kelompok (kelas eksperimen) sebanyak 11 siswa dan kelompok/kelas kontrol sebanyak 11 orang. Penentuan sampel tidak mempengaruhi kealamiahan hasil penelitian karena siswa terteliti memiliki kemampuan yang homogen dengan penempatan yang tidak berdasarkan pada prestasinya.

Adapun Teknik yang digunakan untuk mengumpulkan data penelitian ini adalah teknik tes, yaitu tes tertulis yang berbentuk pilihan ganda. Materi bersumber pada standar kompetensi atau tema tertentu. 
Dalam penelitian ini, data yang terkumpul dianalisis dengan menggunakan teknik statistik deskriptif dan teknik analisis eksperimen jenis uji t. Adapun langkah-langkah menganalisis data sebagai berikut:

1. Membuat daftar skor mentah.

2. Membuat distribusi frekuensi dari skor mentah.

3. Menentukan nilai baku setiap sampel dengan menggunakan rumus:

$$
\text { Nilai }=\frac{S}{S M} \times 10
$$

\section{Keterangan:}

$\mathrm{S}=$ Skor diperoleh siswa

$\mathrm{SM}=$ Skor maksimal (Adaptasi dari Sudjana, 2006: 438 dan Nurgiyantoro 2001)

4. Menentukan perbandingan nilai rata-rata siswa kelas kontrol dengan kelas eksperimen dengan menggunakan rumus uji t, yaitu:

$$
t=\frac{M_{1}-M_{2}}{\sqrt{\frac{\sum X_{1}^{2}+\sum X_{2}^{2}}{N(N-1)}}}
$$

\section{Keterangan:}

$\mathrm{t}=\quad$ perbandingan nilai rata-rata kelas eksperimen dan kelas kontrol

$\mathrm{N}=\quad$ jumlah frekuensi

$\sum X_{1}=$ jumlah nilai kelas eksperimen

$\sum X_{2}=$ jumlah nilai kelas kontrol

$\sum X_{1}^{2}=$ jumlah kuadrat nilai kelas eksperimen

$\sum X_{2}{ }^{2}=$ jumlah kuadrat nilai kelas kontrol

$\mathrm{M}_{1}$ = nilai rata-rata kelas eksperimen

$\mathrm{M}_{2}=$ nilai rata-rata kelas kontrol

d.b. $(\mathrm{NU})=$ jumlah frekuensi $(\mathrm{N})-1^{6}$

${ }^{6}$ Arikunto, Suharsimi. Prosedur Penelitian. Jakarta: Rineka Cipta. 2003. HIm: 278 


\section{PEMBAHASAN HASIL PENELITIAN}

Pada bagian ini diuraikan temuan yang diperoleh dari hasil analisis data penelitian. Analisis data yang dimaksud, yaitu efektivitas kuis dalam meningkatkan hasil belajar IPS siswa kelas VI SDN 8 Keruak Kecamatan Keruak.

Berdasarkan hasil analisis data pretes dan postes kedua kelas penelitian ini, yaitu kelas eksperimen dan kelas kontrol dapat dinyatakan bahwa kuis memberikan kontribusi dan peran terhadap peningkatan hasil belajar IPS siswa kelas VI SDN 8 Keruak Kecamatan Keruak. Hal ini dinyatakan berdasarkan data-data yang ditemukan melalui tes awal dan akhir kedua kelas penelitian ini.

Hasil tes awal kelas eksperimen dan kelas kontrol penelitian ini menunjukkan bahwa hasil belajar IPS siswa kelas VI SDN 8 Keruak Kecamatan Keruak Makassar adalah sama. Artinya, kelas eksperimen dan kontrol mempunyai pemahaman, tingkat hasil belajar, dan pengetahuan materi IPS yang sama. Intinya adalah hasil belajar IPS masih rendah. Hal ini tampak pada tabel 14 berikut ini.

Tabel 2

Hasil Belajar IPS Siswa Kelas Eksperimen dan Kontrol (Pretes)

\begin{tabular}{|c|c|c|c|c|c|}
\hline No. & Perolehan Nilai & \multicolumn{2}{|c|}{ Kelas Eksperimen } & \multicolumn{2}{c|}{ Kelas Kontrol } \\
\cline { 3 - 6 } & Frekuensi (f) & Persentase (\%) & Frekuensi (f) & $\begin{array}{c}\text { Persentase } \\
(\%)\end{array}$ \\
\hline 1. & $\begin{array}{c}\text { Nilai 70 ke atas } \\
\text { Nilai di bawah } \\
2 .\end{array}$ & 0 & 0 & 0 & 00 \\
\hline & Jumlah & 11 & 100 & 11 & 100 \\
\hline
\end{tabular}

(Adaptasi dari KKM Sekolah sesuai dengan KTSP, 2006)

Hasil belajar IPS tersebut menunjukkan bahwa kemampuan awal siswa adalah sama. Persamaan tersebut memberikan indikasi bahwa hasil penelitian pada saat treatmen (perlakuan) dengan menerapkan kuis bagi kelas eksperimen adalah murni dari pengaruh penggunaan kuis. Hal ini dinyatakan karena pemahaman awal siswa adalah sama. Apabila setelah treatmen (perlakuan) terdapat perbedaan hasil belajar kelas eksperimen dan kelas control, maka nilai itu 
merupakan peran pemberian kuis.

Melalui perlakuan ternyata terdapat perubahan nilai setiap sampel, walaupun tidak semuanya mencapai KKM. Akan tetapi, semuanya mengalami peningkatan yang signifikan. Hal ini tampak pada tabel berikut ini.

\section{Tabel 3}

Hasil Belajar IPS Siswa Kelas Eksperimen dan Kontrol (Postes)

\begin{tabular}{|c|c|c|c|c|c|}
\hline No. & Perolehan Nilai & \multicolumn{2}{|c|}{ Kelas Eksperimen } & \multicolumn{2}{c|}{ Kelas Kontrol } \\
\cline { 3 - 6 } & & Frekuensi (f) & Persentase (\%) & Frekuensi (f) & $\begin{array}{c}\text { Persentase } \\
(\%)\end{array}$ \\
\hline 1. & $\begin{array}{c}\text { Nilai 70 ke atas } \\
\text { Nilai di bawah }\end{array}$ & 1 & 9,09 & 0 & 00 \\
\hline & 70 & 10 & 90,1 & 11 & 100 \\
\hline & Jumlah & 11 & 100 & 11 & 100 \\
\hline
\end{tabular}

(Adaptasi dari KKM Sekolah sesuai dengan KTSP, 2006)

Hasil belajar IPS tersebut menunjukkan bahwa kemampuan akhir siswa berbeda. Perbedaan tersebut memberikan indikasi bahwa hasil penelitian pada saat treatmen (perlakuan) dengan menerapkan kuis bagi kelas eksperimen mengalami peningkatan yang disebabkan oleh penggunaan kuis. Hal ini dinyatakan karena pemahaman akhir siswa berbeda.

Berdasarkan hasil analisis data nilai kelas eksperimen diketahui bahwa rata-rata hasil tes siswa yang mengaplikasikan teknik kuis sebelum evaluasi lebih baik adalah 6,0, sedangkan nilai rata-rata hasil tes siswa yang tidak menggunakan teknik kuis sebelum siswa mengikuti ujian (kelas eksperimen) adalah 3,5. Jadi, kelompok siswa yang diberikan kuis sebelum mengikuti ujian/evaluasi mempunyai hasil belajar yang lebih baik daripada kelompok siswa yang tidak tidak diberikan kuis sebelum mengikuti ujian/evaluasi.

Berdasarkan hasil analisis nilai rata-rata kelas eksperimen yaitu 6,0 di atas diperoleh gambaran bahwa nilai tersebut lebih rendah dari standar kelulusan berdasarkan KTSP 2006, yakni nilai 7,0 ke atas harus mencapai 75\%. Akan tetapi, nilai rata-rata kelas eksperirnen sudah menunjukkan peningkatan dan efektivitasnya dibandingkan dengan nilai kelas kontrol. Hal demikian dinyatakan karena esensi penelitian ini adalah mengamati peran dan efektivitas teknik kuis, bukan pada perannya dalam pencapaian standar (KKM). 
Berdasarkan hasil analisis data perbandingan skor rata-rata hasil tes siswa antara kelas eksperimen dan kelas kontrol dengan menggunakan rumus uji $\mathrm{t}$, dapat diketahui bahwa nilai $\mathrm{t}$ hitung diperoleh sebesar 1,12. Dalam penelitian ini, peneliti telah mengungkap bahwa kelompok siswa yang diberikan kuis sebelum evaluasi mempunyai hasil belajar yang lebih tinggi daripada siswa yang tidak diberikan kuis sebelum menghadapi tes/evaluasi. Dengan frekuensi (d.b.) sebesar 11, pada taraf signifikan $90 \%$ diperoleh t.s. $90 \%=0,879$. Jadi, $\mathrm{t}$ hitung $>\mathrm{t}$ tabel. Oleh karena $\mathrm{t}_{\text {hitung }}>\mathrm{t}$ tabel pada taraf signifikan 90\%, maka hipotesis nol (H0) ditolak dan hipotesis alternatif (H1) diterima. Hal ini berarti bahwa kuis efektif diterapkan dalam meningkatkan hasil belajar IPS siswa kelas VI SDN 8 Keruak Kecamatan Keruak. Oleh karena itu, dapat disimpulkan bahwa penggunaan kuis memberikan kontribusi dalam peningkatan hasil belajar IPS siswa kelas VI SDN 8 Keruak Kecamatan Keruak. Dengan kata lain, jika guru memberikan kuis sebelum siswa mengikuti ujian materi tertentu, maka hasilnya akan lebih baik dan meningkat.

Tingginya hasil belajar siswa yang diberikan kuis disebabkan oleh kemampuan siswa menyelesaikan soal yang dihadapi termasuk menjawab tes yang diberikan. Melalui pemberian kuis, siswa mudah menyelesaikan soal karena bahannya sudah sering diungkapkan oleh guru melalui pemberian pertanyaan, baik sebelum mengikuti pelajaran sebagai wujud apersepsi, maupun pada saat sebelum mengikuti evaluasi akhir.

Lain halnya dengan fenomena pembelajaran yang tampak pada kelas kontrol, siswa sulit menjawab soal-soal yang diberikan. Banyak siswa menyontek, tidak percaya diri terhadap jawabannya, serta waktu yang digunakan sangat lama. Sehingga hampir 50\% soal yang tidak mampu dijawab dengan benar oleh siswa.

Mencermati uraian tersebut pemberian kuis kapan pun sangat perlu diterapkan oleh guru. Kuis membantu siswa mengonstruk kembali pengetahuannya berdasarkan materi yang telah dipelajari. Kuis sebagai strategi guru dalam memotivasi siswa dalam belajar. Melalui kuis, siswa akan terus belajar karena mengetahui akan diuji sebelum guru memulai pelajaran.

Idealnya, pada setiap pertemuan guru seharusnya memberikan kuis tentang materi yang telah dipelajari dan menanyakan materi yang akan dipelajari sebagai tujuan mengetahui kemampuan siswa. Selain menarik perhatian dan menumbuhkan motivasi, kuis menciptakan kehangatan dan keantusiasan siswa dalam belajar.

Bentuk kuis yang baik diterapkan tersebut hendaknya bentuk esai. Hal ini dimaksudkan 
untuk mengkaji pengetahuan dan pemikiran siswa. Bentuk esai menggali pengetahuan dan pemahaman siswa terhadap suatu konsep. Guru dalam memberikan kuis hendaknya dilakukan secara teratur. Maksudnya, tidak terlalu dimonopoli oleh pemberian pertanyaan untuk dijawab serentak oleh siswa. Kalau memungkinkan, kuis yang diberikan ditentukan terlebih dahulu siswanya yang akan menjawab. Hal ini dimaksudkan untuk menghindari satu siswa yang sering menjawab karena terkadang dalam satu kelas selalu dimonopoli oleh siswa tertentu. Dengan demikian, semua siswa berhak mendapat pertanyaan dari guru.

Pemberian kuis pada dasarnya menumbuhkan motivasi siswa untuk belajar terhadap materi yang telah dan akan dipelajari. Siswa akan mempelajari materi dengan tujuan mudah menjawab setiap kuis yang dilontarkan kepadanya. Kemampuan siswa menjawab kuis merupakan kebanggaan tersendiri, mendapat apresiasi dari guru, dan terhindar dari rasa malu dari guru dan siswa lainnya. Memang, ketidakmampuan menjawab kuis menjadi tekanan psikologis siswa, mendapat penilaian kurang dari guru dan teman kelasnya. Hal inilah yang juga dapat memotivasi siswa mengulangi materi yang telah dipelajari dan berusaha memahami dan mempelajari materi yang akan dipelajari pertemuan

\section{KESIMPULAN DAN SARAN}

Berdasarkan penyajian hasil analisis data dan pembahasan penelitian ini, dapat disimpulkan bahwa kuis efektif diterapkan dalam meningkatkan hasil belajar IPS siswa kelas VI SDN 8 Keruak Kecamatan Keruak. Artinya, kuis merupakan strategi yang dapat mengubah proses (membentuk perilaku belajar siswa) dan hasil belajar siswa. Hal ini tampak pada kedua kelas penelitian. Bagi kelas kontrol, sikap dan perhatian siswa terhadap pembelajaran IPS masih kurang. Berbeda dengan siswa kelas eksperimen, sikap dan perhatian siswa terhadap pembelajaran IPS sangat tinggi. Peningkatan hasil tampak pada perolehan nilai rata-rata kelas eksperimen lebih baik dibandingkan dengan nilai rata-rata kelas kontrol. Peningkatan dan berpengaruhnya kuis tampak pada hasil uji $\mathrm{t}$, yaitu nilai $\mathrm{t}$ hitung $=1,12$ lebih besar daripada nilai $\mathrm{t}$ tabel $=0,879$ pada taraf signifikan $90 \%$.

Adapun Saran yang dapat diusulkan Sesuai dengan kesimpulan tersebut adalah sebagai berikut: Pertama, Siswa hendaknya lebih meningkatkan strategi belajarnya, bukan hanya karena ada kuis yang selalu diberikan oleh guru, melainkan karena sebuah kebutuhan untuk menambah wawasan dan pengetahuan. Kedua, Bagi guru IPS siswa kelas VI SDN 8 Keruak Kecamatan Keruak agar mempertahankan strategi pembelajaran yang sering memberikan kuis karena dapat 
menumbuhkan sikap positif dan hasil belajar siswa yang meningkat. Dan terakhir Bagi guru IPS pada umumnya yang belum sempat menerapkan strategi pemberian kuis, hendaknya menerapkan pada setiap aktivitas belajar karena dapat meningkatkan minat dan hasil belajar siswa.

\section{DAFTAR PUSTAKA}

.Abdurrahman. 1994. Dasar-dasar Publik Relation. Bandung: Alumni.

Arikunto, Suharsimi. 2003. Prosedur Penelitian. Jakarta: Rineka Cipta.

Azwar, Saifuddin. 1987. Tes Prestasi. Yogyakarta: Pustaka Pelajar.

Depdikbud. 2005. Kamus Besar Bahasa Indonesia Edisi III. Jakarta: Balai Pustaka.

Hamalik, Oemar, 1994. Proses Belajar Mengajar. Bandung: Bumi Aksara.

Nurgiyantoro, Burhan. 1995. Penilaian dan Pengajaran Bahasa dan Sastra. Yagyakarta: BPFE. 